\title{
IMPROVING STUDENTS' WRITING SKILL USING A PROCESS APPROACH
}

\author{
Galuh Nurrohmah
}

\begin{abstract}
Ketua Pusat Penelitian, Pengembangan dan Pengabdian pada Masyarakat Dosen Jurusan Bahasa dan Sastra Inggris

Fakultas Humaniora dan Budaya, Universitas Islam Negeri (UIN) Malang. Jalan Gajayana No. 50 Telepon (0341) 570872, Faksimile (0341) 570872 Malang 65144.
\end{abstract}

\begin{abstract}
Abstrak
Ketrampilan menulis merupakan jenis ketrampilan berbahasa yang membutuhkan baik kemampuan tatabahasa dan pengorganisasian ide. Untuk meningkatkan ketrampilan menulis siswa bukanlah upaya yang sederhana, tetapi merupakan upaya yang membutuhkan cara-cara tertentu. Pengajaran ketrampilan menulis yang selama ini diterapkan di kelas lebih berorientasi pada pendekatan tradisional di mana pengajar ketrampilan menulis menyuruh siswa untuk menuliskan karangan dan karangan tersebut dikumpulkan untuk dikoreksi. Pada pendekatan ini siswa tidak diberi kesempatan untuk memasuki dunia nyata dalam menulis yaitu mencari topik, membuat kerangka karangan, menuliskan draft awal, merivisi dan menulis draft akhir. Langkah-langkah tersebut bisa dijumpai dalam pendekatan proses. Dengan menggunakan pendekatan tersebut dalam pengajaran ketrampilan menulis, siswa merasakan pembelajaran yang bermakna dan siswa dapat meningkatkan ketrampilan menulis mereka.
\end{abstract}

\section{Kata Kunci}

Keterampilan Menulis, Pembelajaran Bermakna

\section{Teaching of EFL Writing}


For students of English as a Foreign Language (EFL), writing in English is a very complex process. It means that writing is such highly sophisticated skill combining a number of diverse elements that require not only grammatical but also rhetorical elements. In addition, among others state coming to learn the organizing and communicating. These skills are the result of years of practice in listening, speaking, reading, and writing.

In other words, in the writing process students should accurately express their ideas in acceptable written English for various purposes including explaining events, telling a story, describing objects, etc. In term of skill to produce a good rhetoric, a good writer must have good ideas, grammar competence, and language skills. He has to use his knowledge dealing with organization of ideas, structure, word choice, spelling, punctuation and knowledge on the subject matter (Heaton, 1989:135). Since the value of writing lies in the craftsmanship, however, writing can be learned.

In addition to the complexity of problems, Mukminatien (1999:3) notes that what makes the matter worse, it seems that writing is not a favorite subject not only for the students but also for the teacher. Furthermore, in view of the various issues in language teaching, especially EFL in Indonesia, have been concerned with the teaching of writing.

The view of problems on teaching writing seems to deal with the focus in language teaching. For this purpose, shift from the manipulation of linguistic items to the use of language for communication purposes has been made. According to Leki (1998:34) when students write in a second language, the purpose of the writing activity seems to be to catch grammar, spelling, and punctuation errors. Under these circumstances, sometimes the only writing do is to write out grammar exercises disguised as composition writing which is so called guided writing. For this purpose, students are given a short text and instructed to change all singular pronouns to plural ones or to 
change present tense to past tense. Consequently, students do not create the texts themselves; they only manipulate forms.

Further, Leki explains that in more advanced classes, students are traditionally assigned compositions or other kinds of texts to write. Most often in these classes, the poor teacher takes home many students papers and carefully marks all the grammatical and mechanical errors in the writing. When the papers are returned to the students, often the students are assigned to take the paper home and correct all the errors and maybe recopy the text into a clean sheet. The focus in these types of writing exercises is primarily on language structure. In addition, previously writing classes deal with sentence-level writing and copying or imitating paragraphs that had been especially written to illustrate different patterns of rhetorical composing process.

Concerning with those problems in the teaching of writing which seem that the use of product approach is the most common way in teaching writing and it does not help the students to master writing skill optimally. The overall emphasis in the product approach, as it is used both with first and second/foreign language learners, is hence on the form of the finished product that the student produces rather than on the process of writing. From this perspective, as a learner's writing proficiency in creases, the learner develops the capacity to handle more complex writing tasks. As this happens, the learners use a greater variety of rhetorical and discourse modes and masters more subtle and complex aspects of paragraph and sentence organization.

\section{The Process Approach}

In recent years, writing researchers have pointed out the limitations of a product approach to the teaching of writing. A product approach concentrates on ends rather than means. By focusing on the form and structure of writing rather than on how writers create writing that has form and structure, the composing processes of good writers are ignored. Murray (2002: 4) observes that process can not be inferred from product any more than a pig can be inferred from a sausage. If our 
goal in teaching writing is to develop fluent writers, it is necessary to examine how fluent writers compose and to reexamine our writing methodology by exploring this particular approach, process approach, deeply.

\section{The Process Pedagogy}

The most important principle of process pedagogy is that writing is the result of a very complex, highly individualized process. Before process pedagogy, writing class generally ignored the writing process. Teachers assigned papers, graded them, and them handed back. They attended to the product-its clarity, originality, and correctness- but they did not attend to the writing process. Nor did they attend to the writers themselves. Sulistyo points out that the problems on writing ability encompass the organization of ideas that may be caused by several factors. Students might aware of their knowledge of paragraph elements but they are ignored about using them in their composition. They might think that as far as their ideas are expressed in sentences that are grammatically correct and meaningfully sensible, nothing matters. Another factor is that the teaching and learning process of writing previously conducted might not have provided the students with sufficient experiences in thinking in English. As a result, they still rely on the thought pattern typical of their mother tongue.

Related to process approach Gocsik (1999: 2) states that the process theorists of the sixties and seventies took issue with this approach to teaching writing. After all, well-written essays do not fall from the sky, it means that they are the results of a long, laborious, intensely personal process that in which writers must address several questions, ranging from what do I write about? To who is my audience? To how do I structure my essay? To what sort of language and voice should I use?

Some people might think that process approach is difficult to implement, but from the process theorist's point of view, it will be different. Process theorists believe that writing can be understood as the 
culmination of several steps in a complicated process. Furthermore, they feel that these steps-which include prewriting, writing, rewriting, and all their attendant strategies can be talked about and modeled. In short, writing as a process can be taught.

\section{A Process Approach to Writing}

Process -oriented writing instruction is based on research into how "real" or "real-world" writers compose texts, a process that differ from the typical student's process of writing for school. The student typically begins a paper late, working under deadline pressure, and produces one draft of the text, runs the spellchecker, prints, and turns in the paper. But in "real-world" writing, most writer produce texts for presentation and publication compose multiple drafts. They often engage as well in a variety of planning activities, solicit feedback, and follow a recursive pattern of drafting, raising questions that require returning to research, then revising in light of new information as needed.

Process-based writing instruction attempts to duplicate this timeconsuming approach to writing in the classroom. Typically, process instruction devotes some time to prewriting or invention activities (getting ideas, beginning to plan), drafting, seeking feedback from peers or the instructor, revising on the whole-text level (looking at the overall focus, reconsidering organization, deciding whether there is enough evidence, etc) followed by revising at the paragraph or sentence level, proofreading, and "publishing" or printing the final text.

The basic question that will come up to our mind is why we use a process approach to teaching writing. This approach is used because it helps the teacher gets the opportunity to intervene in students' writing process at any stage. Effective intervention results in better papers. Students who are asked or required to spend more time on a paper will think more about their topic, retain more information, and develop more powerful insights. Furthermore, students' writing skills need practice in 
order to develop. Finally we will enjoy reading students' papers if their quality is higher.

We all know how depressing it is to read a composition that make poor arguments, fail to follow acceptable formatting conventions, and otherwise violate our sense of what academic writing ought to look like, Trupe (2000:6) . If we have looked at drafts and helped students think through their arguments more thoroughly, we will enjoy reading the final papers more.

\section{Cognitive Process in Writing}

Murray (1980:45) distinguishes three stages in writing: rehearsing, drafting, and revising. Rehearsing, or prewriting involves finding a topic; finding ideas about the topic; thinking about the topic; letting ideas interact, develop, and organize themselves; and thinking about the audience and the purpose of the writing task. At this stage the writer may not know how many of the ideas or how much of the information will be used. Drafting involves getting ideas onto paper in rough form. The writer sketches out an idea, examines it, and follows it through for a while-perhaps letting it follow its own course. What has been written serves to generate further ideas, plans, and goals. Thus the process of writing creates its own meaning. The writer may also go back to the rehearsing phase, and alternate between the rehearsing and drafting phase. Revising involves evaluating what have been written and making deletions or additions as necessary, "to help the writing say what it intends to say" (Murray, 1980:5). However, as Raimes points out, revising can occur at any time in the composing process. The process approach proposed in this paper has adapted from Keh's (1990) model which has the following stages:

\section{Input}

Input sessions consisted of a mixture of idea-generating activities, which included brainstorming/listing, reading, listening, survey-taking, and quick-writing. Brainstorming is a method of idea 
generation in which students are told to come up with as many ideas as possible on a given topic (broad or specific) Keh (1990:10). In this session, small groups are given a statement in which they are to agree or disagree and brainstorm/list as many reasons as possible to support their opinion. The reading materials are taken from various books and the newspaper which are "interactive".

The following step of this session is the students are instructed to write comments in the margins (e.g. "I do not understand the author's point here, or "I agree, "Because it also happens in my country") in order to get used to responding as active readers. Students also listened to lectures and jotted down notes for future reference. Survey is also conducted during this session to interview other people (not classmates) for input from outside sources. The goal of input sessions is to show the students that there are many means of getting ideas for writing.

\section{First Draft}

In this session, the students are assigned to write their writing based on the previous ideas which were gotten from the input session, they are reminded that when writing this first draft, they should not expect perfection or even work towards it. Rather, Singh (1992) says that the first draft was a further means of discovering ideas and what one wanted to say. It means that writing first draft is just like writing a general plan of a paragraph or an essay. Furthermore, students should begin to write with knowledge that they would change the paper later and that change is desirable and necessary in the writing process.

\section{Peer Evaluation}

For the peer evaluation session, students work in pairs or trios. They are given photocopied guidelines to help them focus exclusively on content/ideas as they responded to classmates' written pieces. After responding to the guidelines, readers give their written comments to the author. The writers and readers are encouraged to discuss the papers, answering questions or asking for clarification of comments, etc. Wright 
et.al (2002:11) say that peer evaluation acted as an ice-breaker between students who did not know each other in the first semester on the year. It means that peer evaluation is the medium to make the students more familiar with other friends.

During this session, the teacher circulates among the groups, providing additional guidance or offering opinions (when asked). The teacher prefers not to read too much of anyone's first draft so she/he could respond as a "fresh" reader to their second draft. Dealing with the use of peer evaluation, Xiaochun (1990:35) mentions that it makes the students more aware of his/her carelessness and saying no to himself that he will not make such mistakes next time and also peer evaluation can make the students become aware that there are different ways of saying things.

\section{Second Draft}

The students are encouraged to make changes in content or even to start over. For some students, they are suggested to make an informal outline of their ideas as they made decisions about content. By referring to the comments and corrections given, the students can make their essay to more "understandable" on its content, organization and language. Wright et.al (2002:12) states that writing multiple draft, second draft give the students an opportunity to improve their composition.

\section{Writing Workshops}

The writing workshops consisted of instruction on some element of writing such as description, definition, or coherence. The instruction is always followed by some form of related writing activity. The second drafts are collected during this class session for teacher feedback. The teacher generally reads each draft three times. The first time is to get overall idea of the content and/or to make an outline of the main points. During the second reading, the teacher writes comments about the content (positive reactions, questions, suggestions) on the paper. At the 
third reading, using a different colored pen, the teacher note any particularly distracting grammatical problems or word choices.

\section{Student-Teacher Sessions}

At the student-teacher sessions the teacher speaks individually with the students about their papers. This sometimes meant asking them to tell me the main points of their paper and/or to respond to any questions I had written on their second draft. Grammar aspects are answered only after content has been discussed.

Remedial grammar lessons are also included on this session. These lessons are based on students' common errors and consisted of instruction and some form of activity. Dealing with this session Trupe (2002:2) suggests that if at all possible, schedule brief face to face conferences for discussion of student writing. The purpose of this session is to give the students a chance to clarify what they want to write and create the guinea communication between teacher and students. That is why the teacher questions should be "What do you mean?" or "Can you tell me more about this?" rather than in evaluative statements.

\section{Final Draft}

This step is done after the students-teacher session. Here, the students have to make the revised edition of their composition based on all notes, lists, quickwriters, etc, and the previous draft. This session is an outside classroom activity in which the students are given a chance to find any relevant sources that can be used to support their topic.

Writing the final draft is the "final journey" of the process of writing, it will force the students to perform the best composition. By using the comments given by their teacher, the students can easily change the composition (Horowits' 1989:10)

The Considerations of Using a Process Approach

There are two considerations of using a process approach, they are as the follows: First, it provides individualized instruction and 
contextual teaching and learning in which both of those teaching methods become the current issues on teaching-learning in any field of study and foreign language teaching as well. In term of individualized instruction, Richards (1992:109) states that in process-focused classrooms there is a shift from language-focused activities to learner-centered tasks in which students assume greater control over what they write, how they write it, and the evaluation of their own writing. And also learners now have more opportunities for meaningful writing, are less dependent on the teacher, and work collaboratively with other students.

Concerning with contextual teaching and learning, the implementation of process approach to teaching writing encourages the students to be actively involved in teaching-learning process and the students learn from their friend through pair work, discussion and correcting each other's works. Those benefits are two of twenty characteristics of Contextual Teaching and Learning Diknas (2002:7)

\section{Conclusion}

The process approach proposed is one of many possible ways to teach writing which has been implemented in the writer's writing class. The writer concludes that implementing a process approach has some benefits, they are (a) there have been significant improvements on students' writing in content, organization, and grammar, (b) there is a change in the students' attitude toward writing-more positive and less frustrated, (c) the greatest benefit of this approach is the increased interaction between the student and teacher throughout the writing process. $\square$ 


\section{BIBLIOGRAPHY}

Blass, J. Laurie and Meredith Pike-Baky. 1985. Mosaic: A content-based writing book. New York: Random House.

Caudery, T. 2000. What the "Process Approach" means to practicing teachers of second language writing skills. (Web document). Available: <http://www-writing.berkeley.edu/TESL-EJ/ej04/a3.html>

Chan, Michelle: 1989. Process and Product. New York: Coller-Macmillan.

Calhoun, F.C. 1993. Action Research: Three Approaches. Educational Leadership. 51. 2: 241-244

Gocsik, Karen. 1999. The Process Approach to Teaching Writing. US: Trustees of Dartmouth College.

Horowitz, Daniel. 1986. Process, not product: Less than meets the eye. TESOL Quarterly 20 (1), 141-4.

Joni, T.R. 1990. Pembentukan Kemahirwicaraan: Tantangan bagi Pendidikan Dasar Menyongsong Abad Informasi. Makalah disajikan dalam Seminar Nasional Pengajaran Bahasa dan Sastra Indonesia. IKIP Malang, Malang, 5-6 November 1990.

Keh, Claudia L. 1990. A Design for a Process-Approach Writing Course. English Teaching Forum, 28, 1, pp. 10-12.

Kemmis, 1982. The Action Research Planner. Victoria: Deakin University

Lestari, L.A. 1999. Comments Between Drafts in the Teaching of Writing: One Way of Improving the Students' Composition. English Language Education. Malang: State University of Malang.

Richards, Jack C. 1990. The Language Teaching Matrix. New York: Cambridge University Press.

Tompkins, G.E. 1994. Teaching Writing Balancing Process and Product. New York: Macmillan College Publishing Company.

Wattimury, L. L. 2000. Pembelajaran Menulis Deskripsi dengan Pendekatan Proses bagi Siswa Kelas $V$ SD. Unpublished Thesis. Malang: Program Pasca Sarjana Universitas Negeri Malang. 
Madyono, Suhel. 2002. Pengefektifan Pembelajaran Menulis Eksposisi Melalui Implementasi Pendekatan Proses di Kelas V SDN Percobaan Kotamadya Malang. Unpublished Thesis. Malang: Program Pasca Sarjana Universitas Negeri Malang.

Xiaochun, Li. 1990. Various Ways of Correcting Written Work. English Teaching Forum, 28, pp. 34-36. 